Diviners and Divination in Aristophanic Comedy

Author(s): Nicholas D. Smith

Source: Classical Antiquity, Vol. 8, No. 1 (Apr., 1989), pp. 140-158

Published by: University of California Press

Stable URL: http://www.jstor.org/stable/25010899

Accessed: 18/02/2014 15:30

Your use of the JSTOR archive indicates your acceptance of the Terms \& Conditions of Use, available at http://www.jstor.org/page/info/about/policies/terms.jsp

JSTOR is a not-for-profit service that helps scholars, researchers, and students discover, use, and build upon a wide range of content in a trusted digital archive. We use information technology and tools to increase productivity and facilitate new forms of scholarship. For more information about JSTOR, please contact support@ jstor.org. 
NICHOLAS D. SMITH

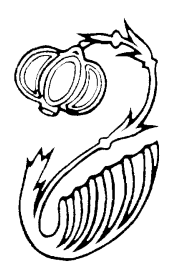

\title{
Diviners and Divination in Aristophanic Comedy
}

\begin{abstract}
Const ONSISTENCY WAS not among the guiding values of ancient comedy. Yet in the extant plays of Aristophanes, ${ }^{1}$ a noteworthy consistency can be found: with rare exceptions, one finds the practice of divination depicted as quackery, and its practitioners accused of fraud. Many scholars have noted this phenomenon in passing, though none has assembled and scrutinized all the pertinent material from the plays. I shall herein attempt to fill this void.

Those who have sought to explain Aristophanes' unflattering depictions of diviners and their practices have interpreted the relevant episodes in the plays in the light of what they contend is a general increase in religious skepticism throughout the end of the fifth and the beginning of the fourth centuries. ${ }^{2}$ Such
\end{abstract}

I have benefited greatly from criticisms of an earlier draft of this paper by Judith M. Engle, David M. Halperin, Michael H. Jameson, John J. Winkler, and the anonymous readers for $C A$. Though many of their suggestions led me to amend my theses, I am solely responsible for any errors that remain.

1. I shall not have occasion herein to discuss Aristophanes' treatment of divination in the lost plays. Though a few fragments contain more or less pertinent material (see PCG III.2: Amphiaraos 29, Farmers 103, Banqueters 241, Danaids 267, Peace II 308, Heroes 324, Telemesses 554), none provides evidence of any consequence to my arguments.

2. See, e.g., Ehrenberg 260-62, and Harriott 103-6. I have portrayed this view with Ehrenberg especially in mind, but Harriott suggests a similar view in discussing not only the exploitation of oracles by men of "quick wits," but also oracles' "slipperiness" (104). The most extreme expression of such a view may be found in Strauss (see esp. 99 and my criticisms of his analysis of Knights infra n.59). (See also my reservation concerning Engle's account infra n.29.) As my arguments will show. I think such views are not warranted by the evidence, for, as I shall argue, many forms of divination are presented without attack, and the only detectable skepticism in Aristophanes' plays appears to be

(C) 1989 BY THE REGENTS OF THE UNIVERSITY OF CALIFORNIA 
scholars conceive of divination, especially as it appears in Old Comedy, solely or mainly as an issue of religious belief, which they oppose to an emerging rationalism. In this paper I shall oppose this view, contending instead that the burden of Aristophanes' satires is borne by the corrupt implementation of divination and the social conditions that both encourage such implementation and render it a danger to the welfare of Athens, rather than by divination itself. The aspect of divination that attracts Aristophanes' satirical notice is its employment as a tactic of persuasion and domination in competitive (and especially political) fora. ${ }^{3}$ About the presuppositions of divination itself Aristophanes has little or nothing to say, permitting his audience to maintain without challenge an uncritical and unreflective acceptance of the basic premises and procedures of Greek religious life. ${ }^{4}$

\section{SEERS AND ORACLE-MONGERS}

During the Peloponnesian War there seems to have been a brisk trade in two skills: soothsaying, and the collection and interpretation of oracles. ${ }^{5}$ Practi-

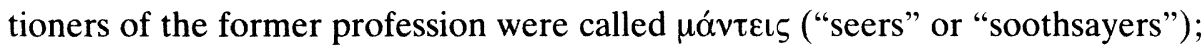

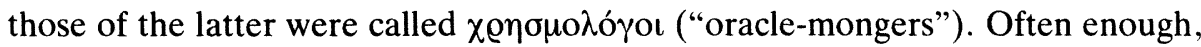

motivated more by distrust of their purveyors than by doubts about the inherent reliability of any forms of divination. Halliday $(94,97)$, Flacelière $(20,68)$, Fontenrose (153-57), Mikalson (41), Nestle (51-52), Nilsson (1972: 136-40), and Oliver (11-16) all discuss Aristophanes' portrayals, but attempt no exhaustive analysis of the evidence.

3. Aristophanes may have represented his own views-and only his own views-in his comedies, though it seems likely that he would be careful always to present those views such a way as to maximize their acceptance by the audience. But the genre of comedy, especially Old Comedy, requires exaggeration and distortion at every turn, so we can have no confidence that what is held up to ridicule in the plays is really disapproved of by Aristophanes or his audience to the same degree as he ridicules it and his audience laughs at it. The example of Kleon-who is attacked more often than anyone else in the plays and yet was at the height of his power and prestige in Athens at the time of Aristophanes' attacks-shows that we cannot suppose that Aristophanes' plays reflect predominant public opinion, however topical the plays may be in subject matter. And the great variety of people and practices Aristophanes ridicules should also make us wary of supposing that the poet always represents his own opinions. For detailed arguments and further discussions, see Halliwell and Hook.

4. The suggestion that the Athenians have become overly religious is made in Aristophanes' Seasons (see PCG III.2, fr. 581, line 15). For obvious reasons of space, I shall not have the opportunity within this paper to discuss Aristophanes' depiction of other religious beliefs, institutions, or practices. But it is worth bearing in mind that gods and heroes were often ridiculed in Aristophanic comedy (for discussion, see Köckert) and that there may be found a number of parodies of prayer (for discussions, see Kleinknecht and Horn). Plainly, it does not follow from the fact that Aristophanes parodies prayer or gods that he wishes his audience no longer to pray or to pay respect to the gods. However, as regards divination, I shall argue that certain of its uses and users are held up to a form of ridicule that does undercut their credibility.

5. See Thuc. 2.8.2; also 2.21.3, 2.54.2, 5.26.4, 7.50.4, 8.1.1; Isoc. 19.5f.; Antiphon 5.81ff.; Xen. Mem. 1.1.3; Plut. Nik. 13, Alk. 17. 
individuals practiced both professions. ${ }^{6}$ Though Aristophanes does not treat them as indistinguishable, his attacks against them typically blur the distinction. ${ }^{7}$ One thing is entirely consistent: neither form of professional divination is even once portrayed in a favorable light in the extant plays.

Of the two types of diviners, the seers are less frequently lampooned, and those that are named are hit hardest when Aristophanes associates them with the expounding of oracles. Thus, Diopeithes and Lampon are both mentioned by name more than once in the plays, ${ }^{8}$ but only Lampon is attacked specifically for being a seer. ${ }^{9}$ Both are mocked as the greatest of cheats and imposters when associated with a pest who is plainly identified not as a seer but as an oraclemonger. ${ }^{10}$ In contrast, when Diopeithes is named without explicit connection to his profession, Aristophanes' jokes are milder: there is no more than a pun on his name ("trust in Zeus") at Wasps 380. The humor is rougher at Knights 108085 , where the context connects him to the manipulative use of oracles, and Diopeithes' hand is identified as a "Twisted Harbor," possibly on the basis of a physical deformity. ${ }^{11}$

6. Argyle (139) and Mikalson (40-41) make a sharper distinction between the two professions than is probably warranted. No doubt Fontenrose is closer to the truth when he says, "Chresmologos and mantis are overlapping terms for a speaker of oracles. Bakis, Hierokles, and Lampon are identified by either title" (153). But even Fontenrose acknowledges that there were certain roles specific to each title (153). Other discussions may be found in Bouché-Leclercq, 1.2.3 (344-74), 2.1.1-2 (1-214); Burkert, II.8.2-3 (111-18); Ehrenberg 260-61; Flacelière 61-69; Garland 80-82, 113-14; Nilsson 1972: 130-40; Oliver 11; Ziehen.

Unfortunately missing from these discussions is any detailed analysis of the basis of these men's authority in interpreting omens and oracles. There may be a number of factors at work in this, including the very access to the divinatory sources such men employed-the oracle-mongers appear customarily to have privately owned their collections of oracles-but no doubt some special training and skill were presumed. (The great seer Teiresias, for example, is the master of a $\tau \dot{\varepsilon} \chi v \eta-$ see, e.g., Soph. Ant. 998ff.; Oed. Tyr. 357, 389.) But in some cases art was no doubt supposed to be augmented by inspiration or talent. Examination of the specific bases of seers' authority is, however, beyond the scope of this study.

7. Thus, when Hierokles appears on the scene in Peace, he is explicitly distinguished as an oracle-monger, and his initial reactions to Trygaios' sacrifice are in character. But soon enough it appears that he wants to take the part of the seer in the sacrifice.

8. Diopeithes: Knights 1085, Wasps 380, Birds 988, and scholia on these; Lampon: Birds 521, 988, and scholia on these; see also Clouds 332 and scholia (see infra n.9), and Eupolis (Golden Race), PCG V, fr. 319; Kratinos (Runaway Women), PCG IV, fr. 66. On Diopeithes, see J. Kirchner, Prosopographia Attica (Berlin 1901-1903) 4309; on Lampon see ibid. 8996.

9. Clouds 332 lumps manteis from Thurii in with sophists of other sorts, and commentators, following the scholiast, are unanimous in finding this a reference to Lampon and/or those associated with him. See Sommerstein, note on Clouds 332 (178); B. B. Rogers, note on Clouds 332 (294).

10. Birds 959-88.

11. Though a purely moral twistedness cannot be utterly ruled out: Agorakritos had proposed interpreting "Twisted Harbor" as referring to Paphlagon's (Kleon's) hand. Kleon's "Harbor" is "Twisted" only in the metaphorical (moral) sense. On this reading, Paphlagon acknowledges the moral meaning of "Twisted," but wishes to deflect its reference to someone presumably more deserving of the reproach. Nothing prevents Aristophanes from employing both literal and metaphorical senses in this case, however: Diopeithes may well have had a twisted hand, and Aristophanes used this fact to accuse him of dishonesty through a double entendre. Ameipsias (10), for example, accuses Diopeithes of circulating forged oracles. 


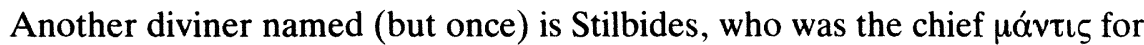
the general Nikias during the invasion of Sicily, but whose death in 413 forced Nikias to rely on other seers whose advice led the general to doom the mission through delay.12 At Peace 1031, Stilbides is said to be "crushed" because Trygaios shows that it takes no special skill to build a fire well enough to perform a sacrifice. One of the special roles afforded to seers was that of assisting the

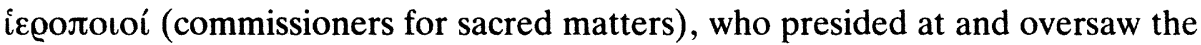
performance of civic sacrifices. ${ }^{13}$ The seer was not only responsible for divining the omens and signs involved in the sacrifices but also for rendering these as favorable as possible by ensuring that the material to be burned was consumed swiftly and completely by the fire (thus signifying its acceptability to the $\operatorname{god}[\mathrm{s}]) .{ }^{14}$ The diviner's reward for doing this was the allotment of various first portions. When Trygaios shows that he has the ability to make his own sacrifice, Stilbides is "crushed" because his claim to a share of the sacrifice is undermined. If there is no need for a seer to make things go well, there is no need to give away choice bits of the sacrifice; the capable amateur may claim the seer's allotment to apportion as he wishes, to himself or to his relatives and friends.

Stilbides' wish to retain the special portions of the seer is clear, but the implicit accusation of greed is only a suggestion until Hierokles ${ }^{15}$ appears on the scene (1046-47). It is plain that Hierokles wants to perform the sacrifice and claim the seer's prerogatives (though this is not Aristophanes' only criticism of Hierokles in this passage, as I shall show later). When Trygaios is not won over by Hierokles' oracular threats, Hierokles is reduced first to begging $(1105,1108$, $1109,1111,1113,1116)$, then to attempted theft (1117-18). Trygaios, not to be denied his sacrifice to Peace, flings Hierokles' oracles back at the seer (1106-14). Hierokles then attempts to steal a share, but Trygaios strikes him (1119). When Hierokles calls for a witness to the assault, Trygaios responds by calling for

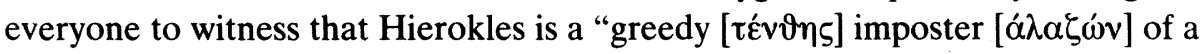
man" (1120) and instructs his slave to keep on hitting "the imposter" with a stick (1121). But Trygaios must do the hitting; the slave is too busy attempting to strip the sheepskins from Hierokles' back, which the slave claims were gotten dishonestly anyway (1122-24). At this point Hierokles flees.

Diviner's greed is apparent, as.well, in the scene with the oracle-teller in the Birds (959ff.). After Cloudcuckooland has been founded, an unnamed oraclemonger appears, claiming to have an oracle from Bakis (about whom, more

12. See Thuk. 7.50; Philochoros 328.135J ap. schol. vet. on Aristoph. Peace 1031; Plut. Nik. 23.7. For a discussion, see Powell. Stilbides and another seer (Amphoteros-never mentioned by Aristophanes) are picked out as the two most significant seers in Athens in Eupolis (Cities), PCG V, fr. $225=$ schol. Ar. Pac. 1031 .

13. [Arist.] Ath. Pol. 54; see Halliday 184-85.

14. See Aisch. Against Ktesiphon 130. Soph. Ant. 1005-7 illustrates that it was most important for the hiera to be consumed swiftly.

15. On Hierokles, see IG $1^{3} .40 .64-67$; Eupolis (Cities), PCG V, fr. $231=$ schol. vet. on Ar. Peace 1046. See Kirchner (supra n.8) 7473. 
later) concerning the new city (961-63). Peisetairos' reactions are first to curse him (960) and then to accuse him of fraud (963-65), but at last, reluctantly, to invite him to chant his oracle. When the oracle-monger does so, it becomes entirely clear that his motives are purely self-serving (967-79). Accordingly, Peisetairos responds with his own oracle (983-88):

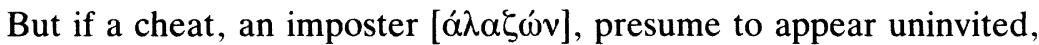
Troubling the sacred rites, and lusting to taste of the inwards,

Hit him betwixt the ribs with all your force and your fury.

See that ye spare not the rogue, though he soar in the clouds as an Eagle, Yea, be he Lampon himself or even the great Diopeithes. ${ }^{16}$

Peisetairos then curses and strikes the oracle-teller and chases him off (989).

As each of these examples shows, it is not just the diviners' greed that Aristophanes holds up to ridicule; he repeatedly has his characters accuse diviners of being impostors and frauds as well. ${ }^{17}$ They are suspected of writing their oracles to fit the events after the fact, ${ }^{18}$ and of selecting and interpreting their oracles misleadingly to serve their own ends. ${ }^{19}$ Often, the motive for their imposture is simple self-seeking, as the example from the Birds illustrates.

But the scene with Hierokles in the Peace shows that sometimes the danger posed by the oracle-tellers is more serious. Hierokles is not only corrupt, he lends his religious authority to a dangerous political position, favoring the war effort. As soon as Trygaios recognizes Hierokles, he can tell that the latter is going to make some objection to the peace agreement (1048-49), though Trygaios' slave supposes that the oracle-monger was drawn by the aroma of the sacrifice (1050). The slave's suspicion is not wholly mistaken, but Trygaios is right, too: as soon as Hierokles learns that the sacrifice is to Peace, he intones $\tilde{\omega}$

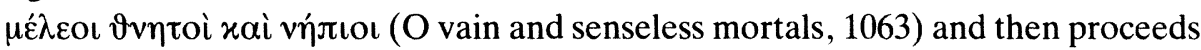
to utter a series of oracles or parts thereof designed to dissuade Trygaios from his sacrifice (1064-1110).

Thukydides tells us that after they became aware of the Sicilian disaster, the Athenian people "became angry with the oracle-mongers and seers and all who at the time had, by various methods of divination, encouraged them to believe

16. Trans. Rogers.

17. See, e.g., the forms of $\alpha \lambda \alpha \zeta \omega ́ v$ (imposter) at Peace 1045, 1069, 1120, 1121; Birds 983; $\varphi \varepsilon ́ v \alpha \xi$ (deceiver) at Peace 1087. That some seers were inaccurate, if not outright fraudulent, is

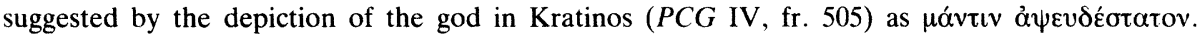
Plainly, for the term to make sense, at least some seers do not tell the truth. See also á $\psi \varepsilon v \delta o ́ \mu a v \tau ı \zeta$ at Nikochares Agamemnon fr. 1 A (Edmonds).

18. See Peace 1085; Birds 963-65.

19. This criticism is implicit in virtually every appearance of an oracle-monger in the corpus, but see esp. Knights 1025-27. The charge that the seer has corrupted his art for personal profit is not only to be found in comedy; it is also an accusation against seers we find repeatedly made in tragedy. (See, e.g., Soph. Ant. 1033-47, 1061, and esp. 1055; Soph. Oed. Tyr. 380-403; Eur. Bacchae 25557.) The very fact that professional seers sought profit from prophecy might well call their impartiality into question. 
that they would conquer Sicily." 20 Aristophanes, however, can hardly have been disillusioned: after all, from their first appearance in his plays, such diviners had not been trustworthy. Nor can Aristophanes be faulted for having been a warmonger, for his plays consistently call for peace and reconciliation between the warring cities. But Aristophanes' portrayal of Hierokles in Peace accords well with Thukydides' suggestion that many of the seers and oracle-tellers put the authority of religion behind the war-mongers. This, too, then, appears to be an important source of Aristophanes' hostility toward diviners.

This hostility is never clearer than in the Knights, where Aristophanes turns the most famous war-monger of all, ${ }^{21} \mathrm{Kleon}$, into an oracle-monger. From the beginning of that play (61), Paphlagon (=Kleon) is said to employ oracles to manipulate Demos (=the people). In their attempt to escape the tyranny they suffer at the hands of Paphlagon, the two other slaves ${ }^{22}$ decide to steal (at least some of) the Paphlagon's oracles (109-43). Having done so, they discover one that prophesies that a sausage-seller will replace "the tanner" (=Kleon). Eagerly conscripting the first sausage-seller they see, ${ }^{23}$ the two slaves conspire to hasten the Paphlagon's overthrow (153ff.). The Sausage-seller at first reacts with disbelief (178-79), but the oracle is read aloud (1977-201):

But when the crook-taloned eagle of leather shall seize

in his beak the blood-quaffing blockhead serpent,

even then perisheth the garlic-brine of the Paphlagons, and to the sellers of tripe the god grants great glory,

sith they prefer not rather to vend sausages. ${ }^{24}$

A comical interpretation of the oracle follows, after which the Sausage-seller is won over (203ff.).

Beginning at 960, Paphlagon (who has somehow found more oracles from Bakis $^{25}$-1003) and the Sausage-seller (who says his are from Glanis [sheatfisha kind of catfish], Bakis' older brother-1004) begin a contest of oracles as they vie for the favor of Demos (1015ff.). Both appear to have an inexhaustible supply (997-1000).

20. Thuk. 8.1.1, trans. Rex Warner (New York 1954). See Plut. Nik. 13.2, 14.7; Paus. 8.11.12. Parker doubts the stories of all the oracular consultations and answers before the invasion (308-9). See also Parke and Wormell, nos. 166-67 and vol. 1, 199.

21. See Peace 269-70, 647-48; Thuk. 5.16.

22. Probably Demosthenes and Nikias, and usually named as such in the translations. For discussion, see Dover 95.

23. Nothing in the oracle itself (see 197-201) requires that the first sausage-seller they encounter will be the one to oust the Paphlagon, so this conscription appears to be a perilous one. But Aristophanes is probably playing on the "first one encountered" theme in so many reported oracles (see Plut. 40-43, and my discussion of that passage, with notes, below).

24. Trans. Sommerstein.

25. On Bakis, see schol. vet. on Ar. Peace 1070-71; Paus. 4.27.4; 10.12.6-11; Hdt. 8.20.2; 8.77; 8.96.2; 9.43; Ael. VH 12.35; O. Kern s.v. Bakis, RE 2801-2 (1896). Platnauer suggests that Bakis was probably not a personal name, but derived from $\beta$ á́દıv (note on Peace 1072). 
There follow a number of volleys of oracles, each of which allows the Sausage-seller to one-up the Paphlagon. Becoming desperate, the Paphlagon changes tactics and tells Demos of a dream he had (1090-91) in which he saw "our goddess herself pouring health-and-wealth over the Demos with a bathman's ladle." But the Sausage-seller can best him even in this form of divination: he responds (1092-95) by "remembering" a dream in which he saw "our Goddess herself come out of the Acropolis, an owl perched on her helmet; then with a decanter, she poured over your [the Demos'] head a libation of ambrosia, and over his [Paphlagon's] one of garlic brine." With this, Demos declares himself won over to the side of Glanis (Sausage-seller's source of oracles-1004).

But the Paphlagon is not quite ready to quit. He claims he has a Pythian oracle saying by what man he will be beaten (1229-30). At 1232 he begins to test the Sausage-seller to see if he fits this oracle. In a brilliant satire of tragic anagnorisis, ${ }^{26}$ step by step the Paphlagon comes to see that his destiny is upon him.

Aristophanes shows us in these passages a demos that is "Sibyl-mad," addicted to oracles. Though of course a comical caricature, this accords well with the historical accounts of Athens during this period. ${ }^{27}$ The poet also portrays Kleon as being altogether too willing to feed the demos's addiction in a manipulative way. For this we have no direct evidence, other than that provided by Aristophanes himself. But Kleon is everywhere portrayed as playing the demos in whatever way he can, and the connection Aristophanes and Thukydides ${ }^{28}$ make between seers and the war effort suggests that Aristophanes' caricature is not wholly inaccurate.

Aristophanes' plays call our attention to the phony, self-serving diviner, whose political employment of oracles is a threat to the welfare of the city, especially by being an obstacle to peace. ${ }^{29}$ And though Aristophanes once in-

26. For a discussion and analysis of this scene, see P. Rau, Paratragodia (Munich 1967) 168-73.

27. See the references supra n.5, and Jordan, esp. 134-37. Fontenrose, for example, speaks of a "swarm of oracles that circulated through the Greek cities in the fifth and fourth centuries" (152). See also Ehrenberg 260; Garland 82; Nilsson (1940) 123 and (1972) 123-42. One might wonder if oracles were more popular during the fifth and fourth centuries only because there would always be an increase of interest in divination during times of crisis (in whatever century), as Jordan suggests (135).

28. See my discussion of Peace, and supra nn.21 and 27. Platnauer goes so far as to say that "in peacetime the soothsayer's occupation is gone" (note on Peace 1085).

29. Engle suggests another aspect of the oracle-mongers' profession that drew Aristophanes' fire: "By making [the Paphlagon] an oracularizer [the Knights] measures him against a traditional speech role - that of prophet-and it sets his babblings against genuine oracles and thus a brand of speech epitomizing what is entailed by magico-religious language" (49). (See Pl. Sph. fr. 147A [Edmonds].) But the Paphlagon's use of oracles, Engle says, "is the very converse of the magicoreligious language of the epic, or, indeed, of genuine oracular speech . . . it is not a language that belongs to the community or reflects the shared values of Athens. His language is fundamentally idiosyncratic" (50). Engle sums up: "Like the parasite who has cornered the market on the Demos" food supply, the Paphlagon has monopolized that other commodity of this city whose very survival depends upon the circulation of language, of words, opinions, verbal transactions in the market 
cludes diviners among the sophists, ${ }^{30}$ it would appear that oracles are the tools of demagogues. Given Aristophanes' willingness to slander Sokrates and the Sophists in the Clouds, it is noteworthy that he does not accuse them of this particular malignancy, especially in the case of Sokrates, who did, after all, claim to have his own private divinatory "sign." ${ }_{11}$ The Sophists in general, and Sokrates in particular, may well have been supposed by Aristophanes to be tricksters who threaten the welfare of the city. But their tricks are of a different sort. ${ }^{32}$ In this one instance at least, then, Aristophanes' portrait of Sokrates coheres well with those of Plato and Xenophon. The abuse of divination seems to have been more the specialty of the demogogues.

\section{MODES OF DIVINATION}

One might suppose, by reviewing the passages discussed above, that Aristophanes was indiscriminate in his lampooning of divination, but in fact his ridicule was more selective. Four sources of divination are plainly identified in the corpus: omens, birds, dreams, and oracles. ${ }^{33}$ Divinatory practices involving

place, and debate in the assembly. He has monopolized meaning" (61). Of course, as the play shows, not all the Paphlagon's oracles are false. It is his use of them we must distrust--see my discussion of the various types of oracles, and infra nn.56 and 57). But Engle's conclusion, it seems to me, applies as well to the other episodes involving oracle-mongers as it does to the Paphlagon in Knights.

30. Clouds 332.

31. On Sokrates' daimonion, see PI. Ap. 31D, 40C, 41D; Euthphr. 38; Euthyd. 272E; Rep. 6.49C; Phdr. 242B; [PI.] Theages 128 ff., 129B; Xen. Mem. 1.1.2, 1.1.3-4, 4.8.1; Ap. 4-5, 8, 12-13. Plato and Xenophon both attribute to Sokrates a sincere general belief in divination (Pl. Ap. 33C; Xen. Mem. 1.1.3-9, 1.4.15, 2.6.8, 4.3.12, 4.3.16-17, 4.7.10; Ap. 12-13), and both say that a Delphic oracle changed Sokrates' life (PI. Ap. 20E-23C; Xen. Ap. 14). For discussion of the relation of the oracle to Sokrates' philosophic "mission," see Thomas C. Brickhouse and Nicholas D. Smith, "The Origin of Socrates' Mission," Journal of the History of Ideas 44 (1983) 457-66. For discussion of the role of divination and the daimonion in Socrates' epistemology, see Brickhouse and Smith, "The Paradox of Socratic Ignorance in Plato's Apology," History of Philosophy Quarterly 1 (1984) 125-31, and "The Divine Sign Did Not Oppose Me': A Problem in Plato's Apology," Canadian Journal of Philosophy 16 (1986) 511-26.

32. For discussions, see Ivo Bruns, Das literarische Porträt der Griechen (Berlin 1896) 181-85, 196-200; Kenneth J. Dover, "Socrates in the Clouds," in The Philosophy of Socrates, ed. Gregory Vlastos (Notre Dame 1980) 50-77; Martha Craven Nussbaum, "Aristophanes and Socrates on Learning Practical Wisdom," in Yale Classical Studies 26: Aristophanes: Essays in Interpretation, ed. J. Henderson (Cambridge, Eng. 1980) 43-97.

33. Omens are also mentioned in Kratinos (Wealth), PCG IV, fr. 171, line 53; see fr. 162 (Edmonds) line 11, for reconstruction; Metagenes, fr. 18 (Edmonds); Anon. fr. 49 (Edmonds). Divination by birds is not mentioned in any of the fragments of lost plays, to my knowledge. Dreams are mentioned in Kratinos Runaway Women, fr. 58A (Edmonds); Krates, PCG IV, fr. 49; Pherekrates Servant-Trainer, fr. 39 (Edmonds); Strattis, Atalanta fr. 3 (Edmonds). Oracles are mentioned in Kratinos, PCG IV, fr. 354; Eupolis' (Cities), PCG V, fr. 249; Plato Adonis, fr. 3 (Edmonds); Plato Greece, fr. 27 (Edmonds); Anon. fr. 9A (Edmonds).

One or two other modes of divination may be found in Aristophanes' plays, but do not require special attention. One of these, using the tail of the animal in a burnt-offering sacrifice, is barely referred to at Peace 1054-55 (see schol. vet. on Peace 1054). (It is interesting that by far the most common form of divination-by the entrails and other parts of animals at sacrifices-is never fea- 
three of these are only rarely depicted, and then, perhaps surprisingly, they are treated quite mildly. I shall discuss each, in the order I have mentioned them.

Only once does an omen appear. At Acharnians 170, Dikaiopolis feels a drop of rain and says it is a "sign from Zeus" ( $\Delta$ เoonuí $\alpha)$ that the Assembly should not meet. It is an easy joke for Aristophanes to make-since "Zeus" often means just "sky" - and the action of the play is in no way affected by Dikaiopolis' desperate but feeble attempt to call off the forces of war. Aristophanes' reservations about the political use of divination may be seen in this example; after all, Dikaiopolis is trying to manipulate people on a political issue through divination. But the attempt is a paltry one made by a sympathetic character, and it fools no one. One is left with no uneasiness about divination in this case, for it is but a comic attempt by a character to pervert divination to his own purposes; it is at most a comment on a social practice, not on religious procedures. In any case, it would appear that Aristophanes sees no particular threat in this form of divination, for otherwise we would surely somewhere see a nastier version of its employment.

Divination by birds is also mentioned but once, ${ }^{34}$ naturally enough in the Birds, where because of their role in divination, the chorus of birds claims to have a role in all sorts of divinatory practices (716-22). The birds' claim is plainly exaggerated for comic purposes, but Aristophanes' humor in this case is without acid. Giving these words to the chorus is, of course, entirely compatible with complete skepticism about the value of divination by birds. But if so, no special hostility is apparent in addition, and skepticism is in fact not implied.

Divination by dreams is mentioned three times; once amiably, and twice more acerbically. Wasps begins with the two slaves, Xanthias and Sosias, comparing their dreams (13-14). First Xanthias tells his, and it turns out to be a version of Aristophanes' standard joke about the cowardice of Kleonymos (15-23). ${ }^{35}$ Sosias' dream is more elaborate (31-45), but amounts to a series of jokes at the expense of a few of Aristophanes' favorite political targets, Kleon (38), ${ }^{36}$ Theoros $(42,45,47),{ }^{37}$ and Alkibiades (44). ${ }^{38}$ When Xanthias interprets Sosias'

tured in the plays, with this sole exception. See also Plato Afflictions of Zeus, fr. 51 [Edmonds].) Delatte has suggested that yet another mode of divination, catoptromancy (divination by mirrors), appears at Ach. 1128-31, where Lamachos sees in his freshly oiled shield "an old man being indicted for cowardice," and Dikaiopolis retorts that in his freshly honeyed pastry he sees an old man "telling Lamachos . . . to go to hell!" Though this joke almost certainly does involve catoptromancy, nothing of particular significance to my thesis may be found in it.

34. Unless one wishes also to count Birds 521, which barely connects Lampon to divination by birds. Though dishonesty is suggested here, it would appear to be attributed to Lampon rather than his method of divination.

35. See Acharnians 88; Knights 958, 1290-99; Clouds 353-54; Wasps 19-23; Birds 1473-81. See also $I G 1^{2} .57 .34$ and 65.5; SEG 10.73; Eupolis, PCG V, fr. 352; Andok. 1.27.

36. Xanthias begs Sosias to stop telling his dream because it "has a horrible smell of rotting hides" (Wasps 38, trans. Sommerstein).

37. See Knights 608; Clouds 400; Wasps 42-51, 418-19, 599-600, 1236-42.

38. Ancient references to Alkibiades are too numerous to list, but see esp. Plut. Alk. 
dream as a good sign, the latter sarcastically offers to hire the former as a dream interpreter at a wage of two obols (52-53). ${ }^{39}$ The entire episode provides Aristophanes with an excuse for a few easy jabs at important political figures, and no comment on the mode of divination is implied. It does appear that dreams are in need of interpretation, and that the process of interpreting them can be problematical. But no skepticism about the divine origin or meaningfulness of dreams is suggested in the Wasps, nor is the audience shown that the problems of interpretation are insurmountable (as they would deduce if, for example, Aristophanes implied that no one could honestly earn the two-obol wage). Without going on in the Wasps to satirize this form of divination for its own sake, or even the follies of its professional practitioners, Aristophanes moves on to other subjects.

But in the Knights a somewhat more critical note is sounded when, as I have already mentioned, in the duel of oracles between Paphlagon and the Sausageseller the final volley is fought with dreams each claims to have had. It is clear throughout the duel, including the final volley, that Paphlagon's motive is to manipulate the Demos by divination. This charge is made explicit later in the play (at 809 , the only other mention of dreams in the corpus). One is led to suspect not only Paphlagon's motives, but his honesty, as well. ${ }^{40}$

But the problem Aristophanes raises does not really demonstrate a rejection, or even really a questioning, of the legitimacy or value of divination by dreams. His plays depict the cheating of people by other people, in this case through the dishonest appeal to a form of divination. Aristophanes never suggests that the dream interpreters should be distrusted in general; ${ }^{41}$ indeed, as a class of professionals they go unmentioned with the sole exception of the bland joke at Wasps 52-53 discussed above. It cannot be that dreams were never employed for political purposes, or Aristophanes' caricature of Paphlagon as doing so would be senseless. It may be that reservations regarding the authentication of dream-reports were widely shared, and thus that the relevant abuse was rare; or it may be that the professionals were never as actively culpable as Aristophanes found the oracle-tellers to be. The latter seems likely to me. For one thing, professional dream-interpreters would ordinarily interpret others'

39. See Sommerstein, note on Wasps 52 (156). See also infra n.41.

40. See Hyperides 4.15-16 (Kenyon) and Aisch. 3.77. Other reservations about dreams may be found in Pl. Lg. 10.909E-910A; Theophr. Char. 16.4, see also 16.11, 25.2; Xen. Ana. 3.1.11-12; Diogenes Cynicus ap. D.L. 6.43. The type of dream in question is discussed by Artemidoros 1.2: "public" dreams had by one person (usually a politically active person) and significant for the destiny of the entire group. Artemidoros cites Agamemnon's dream in Il. 2-and it, of course, is a case of deception. So distrust of dream-claims in political contexts would appear not merely to be a phenomenon of the late fifth and early fourth centuries. For general discussions of this form of divination, see Bouché-Leclercq 1.2.1 (277-329); Dodds 102-11, 117-21. For a discussion of dreams in inscriptions and reliefs, see Straten.

41. Reckford suggests that Wasps 52-53 may be a reference to a well-known fraud: "The twobit dream interpreter belongs with the oracle-monger and other itinerant fortune-tellers" (290). As my argument shows, I am not persuaded that one can see this in Aristophanes' treatment of the matter. On dream interpreters, see Plut. Aristid. 27; Xen. Anab. 7.8.1. 
dreams, not their own. One might insist on interpreting one's own dreams, or even lie about the dreams one has had, but this would be a tricky business-even a carefully concocted report of a dream could invite alternative interpretations, and if one were not a trained dream-interpreter one's own interpretation would be all the more open to amendment. Finally, the gods would not always give private individuals answers that would serve equally well for others or for the entire state: as Lycurgus says, ${ }^{42}$ "it would be terrible if the same divine signs appeared to the pious and to the wicked." So the dreams of the wicked, even if interpreted properly, might not be viewed as appropriate signs for all to follow. The message, like the medium, might be purely private.

In contrast to the above forms of divination, there are many oracles reported in the Aristophanic corpus, from a variety of different sources. Many of these are actually read aloud or recited by characters. Usually those that are presented aloud are in a form and meter peculiar to them, and frequently enough they contain portions or phrases from well-known oracles, ${ }^{43}$ but nearly always these familiar aspects very soon give way to absurdities and burlesques.

Oracles are the commodities of the oracle-mongers about whom Aristophanes has so many reservations, and so, as one might suspect, there is much criticism to be found in his plays in regard to this mode of divination. Aristophanes' characters cite oracles they attribute to at least three different well-known sources:44 Bakis, the Sibyl, and, of course, the Pythia. The former two are treated as equivalent in the plays. So, for example, at Knights 61, where the Paphlagon is said to seduce the Demos with oracles, the latter is said to be "Sibyl-mad," but later on, the principal source of the oracles the Paphlagon uses is said to be Bakis $(123,1003)$. The same interchange of the Sibyl and Bakis can be seen in the Peace where Hierokles claims his authority is Bakis (1070-71), and is later identified with Bakis (1119), but rejects Trygaios' citations from Homer on the grounds that they did not come from the Sibyl (1095, cf. 1116).

Oracles attributed to Bakis and the Sibyl were similar in at least one important respect: they were all collected in books and could be selected for employment at any time by the oracle-monger, according to his perception of their relevance or usefulness. In addition to the oracles attributed to Bakis and to the Sibyl, Pythian oracles could also be collected, and it is clear that in many cases an oracle originally from one source would end up being attributed to another source. ${ }^{45}$ Many oracles read from collections would not even be attributed to one or another source when cited. But as studies of the varieties of oracles show,

42. Leoc. 93.

43. See Knights 1013, 1086-87-this oracle is presumably the same as Parke and Wormell's no. 121 (see also vol. 1, 185) and Fontenrose's Q180 (327; discussion on 150-51). Also, compare Knights 1040 to Hdt. 7.141, which mentions a similar oracle prior to the battle of Salamis.

44. In addition to invented sources, e.g., "Glanis" at Knights 1004. On the name Glanis see Weinrich.

45. See Fontenrose 145-52, 165 
there were differences in their diction ${ }^{46}$ and Aristophanes' burlesques show signs of being parodies of certain identifiable sorts.

A few scholars have suggested that Aristophanes portrays Delphic oracles with a great deal more respect than he shows for those attributed to Bakis or the Sibyl. ${ }^{47}$ I am convinced this is correct. But the reason scholars offer for this difference is Aristophanes' more unreserved acceptance of Delphic authority. I think more needs to be said. What is at issue, if I am right, is not the relative authority of the various oracular sources so much as the uses of oracles in political competition. A careful look at the differences between the varieties of oracles will explain precisely why Aristophanes would exempt Delphi from his attacks on oracles.

There are a number of differences between oracles collected in books and oracles obtained by an actual consultation at an oracular shrine, such as Delphi. For one thing, the latter are very specific responses to very specific questions, questions sometimes carefully and very deliberately formulated in advance ${ }^{48}$ and delivered, presumably, in the presence of witnesses. The Pythian response to these questions had an immediacy to it, and its relevance to issues was established, within reasonable parameters, by the questions and those asking them. Though these oracles were often of grand political significance, the manner in which they were obtained did not often encourage subsequent use by others who were not initially involved in the issues that led to their utterance. The oracles collected in books, however, whatever their source, were collected precisely because they promised more general applicability. Thus, they were far more useful to those seeking to use oracles for manipulative political purposes. And being the private property of their collectors, these oracles were susceptible to tampering, even to outright fraud. ${ }^{49}$

46. See Fontenrose 146, 154, 161, 168-86. See also Burkert 117

47. See, e.g., Ehrenberg 260; Mikalson 41; Parker 302. Parke and Wormell think that Aristophanes was hostile even to Delphi in his earliest plays, though "[i]n his later plays, Aristophanes" satire is less specifically directed towards the Pythian Apollo" (vol. 1, 193). As my argument will show, I see no such hostility early or late in the Aristophanic corpus.

48. For examples, see Hdt. 1.67, 5.79; Xen. Anab. 3.1.5-7; Paus. 10.18.2. For discussions of the ways in which the questions asked were worded and the significance of such wordings, see Mikalson 43-45; Parker 302-3; Pritchett 296-321.

49. So Engle 58: “The Paphlagon says the oracles came from Bakis (1003). But doesn't the Knights make a point of implying that oracular language is easily imitated? How can we trust the Paphlagon's claim, in that case, that his logia issued from the mouth of Bakis? Aren't we rather to gather that the oracles are rank fakes composed by the Paphlagon himself and designed to enhance his stature in Athens?" Also Fontenrose 165: "There was a good deal of pious fraud in the gathering and keeping of oracle collections; and there was a good deal of credibility and superstition in the popular acceptance of circulating oracles."

The most infamous case of such a fraud was Onomakritos' invention of an oracle which he attributed to Musaios-see Hdt. 7.6. The Sausage-seller's name, Agorakritos (1257), which is an nounced immediately after the Paphlagon is finally defeated by the Pythian oracle (1230-53), is suggestively close in sound to Onomakritos. It is possible that Aristophanes' decision to name the Sausageseller at this moment in the play is designed to make this connection; certainly the Sausage-seller's victory over the crafty Paphlagon shows that the former's ability to manufacture oracles is unexcelled 
Because of the immediacy and unpredictability - uncontrollability, really ${ }^{50}$ of the Delphic oracle, crooked oracle-mongers could not depend upon it to provide a good source of tools for their trade. Accordingly, not once in Aristophanes do we see an oracular shyster calling for a pilgrimage to Delphi or any other oracular shrine for a consultation. Their apparent reticence cannot stem from Delphi's geographical or political inaccessibility, ${ }^{51}$ for other shrines were always available and were frequently consulted when Delphi could not be. ${ }^{52}$ The willingness of oracle-mongers, in Aristophanes, to cite the authority of oracles but not once to call for a Pythian consultation signifies their desire to control the process of divination. This strongly suggests dishonesty.

Further evidence for the view that Aristophanes' criticisms are directed only against the collected oracles of the oracle-mongers, and not those announced at oracular shrines, may be found in Aristophanes' strikingly unskeptical tone in the one instance of an oracular consultation in the plays. The Wealth begins with such a consultation: the aged Chremylos has gone to ask whether his son, a good man, should become wicked in order to succeed. Appearances suggest to Chremylos that good men remain poor and luckless, while temple-robbers, orators, sycophants, and villains grow rich and prosper (32-38). The reply Chremylos receives is a puzzling one: he should befriend and take home the first person he sees upon leaving the shrine (39-43). This is a uniquely Delphic style of response, belonging to a famous genre of Delphic oracles. ${ }^{53}$ Karion, Chremylos' slave, is appalled to find his master following around a blind old beggar (8-17). But Chremylos persists in following the oracle's advice (51-55), and of course,

50. There are, of course, stories of the Delphic oracle being misreported or influenced in some way (see, e.g., Hdt. 1.158; 5.63, 90-91; 6.122; 6.66, 75; Thuc. 5.16.2; Theog. 805-10; Plut. Nik. 13.5-6), but these are surprisingly few, and problematical. For discussion of cases such as these, see Nilsson (1972) 128-30; Parker 324-26.

51. During the war, travel to Delphi might be difficult or impossible for political reasons. This is presumably why free access to Delphi was stipulated in the Peace of Nikias in 421: see Thuc. 5.18.2; also 4.118.1-3. For discussions, see Garland 80-81; Halliday 64-65; Lloyd-Jones 70; Parke and Wormell vol. 1, 233-43; Parke 141-43, 216-17; infra n.52.

52. See, e.g., the use of Dodona in Xen. Vect. 6.2-3; Dem. 19.297-99, and 21.51-53; Hyperides 4.24-25 (Kenyon). See also Kratinos (Archilochuses), PCG IV, fr. 5. Ammon and Dodona are both mentioned, along with Delphi, at Birds 716 .

53. See the oracles reported in Fontenrose as Q109 (304-5); Q129 (311); L2 (355-56); L28 (366); L79 (384); L82 (386), to which compare Didyma 1 (417); L128 (399). See also Fontenrose's discussion of this theme on 15-16. It should be noted that none of the above oracles is viewed by Fontenrose as historical. The scene is, then, based on literary conceptions and not on the historical realities of Delphi.

Strauss's idiosyncratic understanding of Aristophanes cannot permit this scene to be taken in the obvious and tradition-supported sense; so he declares that "it was a mere accident, not foreseen by Apollon, that Plutos was the first one whom Chremylos met when leaving Apollon's temple" (287). It does not appear to trouble Strauss that such a view makes the entire episode patent nonsense and wholly subverts its contribution to the play. In fact, Strauss plainly takes this to be a virtue of his interpretation, which concludes that "Chremylos' pious interpretation [of the oracle] leads in a manner to the destruction of piety" (288). 
the blind old beggar turns out to be Wealth personified (78). So the oracle was indeed a proper and beneficial answer to Chremylos' question, for during the play Wealth's sight is restored, and thus he becomes rehabilitated and made at long last to work for the good, hard-working, honest, common man. Chremylos' son need not become a bad man in order to succeed.

Of course, this use of the oracle is first and foremost a plot device: the oracle is not an object of scrutiny in its own right. But its employment in this way would be fully compatible with jokes about other oracles that were hopelessly off the mark, for example, or jokes suggesting that oracles were all nonsense. But the characters in the Wealth do not in the least question the truth of this (or any other) oracle; the differences of opinion between Chremylos and Karion involve differences of interpretation. Those who do not believe in oracles do not take them seriously enough to find them in need of interpretation.

It would perhaps be more convincing if this exceptionally uncritical portrait of an oracle did not appear in Aristophanes' last extant play. One might suppose that the Wealth, which was produced long after the apparent discrediting of the oracle-mongers after the Sicilian disaster,${ }^{54}$ shows only that oracles in general were no longer being misused in Athens. But the evidence from Aristophanes' earlier plays also suggests that the Delphic oracle is exempt from ridicule.

Oracles read from books within the plays, for example, are almost invariably presented as manipulative frauds. This is evident, for example, in Hierokles' oracles in the Peace, which as I have said, are all attributed either to Bakis or the Sibyl, but are never said to be Pythian. The same can be said in regard to the unnamed oracle-monger of the Birds, whose oracle is from Bakis $(962,970)$. It is noteworthy that when Peisetairos retorts with his own oracle, he claims Apollo alone as his source (982), ${ }^{55}$ though it is clear nevertheless that his oracle, too, comes from a book. Even when an otherwise sympathetic character produces a written oracle, it is plain in context that it is a fraud: so it is in Lysistrate when the title character recovers the solidarity of the women by reading a dubious oracle at 770-76.56 All but one of the Paphlagon's oracles in Knights (997-1000), whatever their source, ${ }^{57}$ are tainted by their having been collected for political use. The one exception-which the Paphlagon has suppressed-describes the man

54. Thuk. 8.1.1.

55. See Fontenrose 164-65.

56. Though never attributed, Lysistrate's oracle is, notably, in the Bakid style, beginning with " $\alpha \lambda \lambda$ ' óлó $\alpha \nu$ " (770). See the references supra n.46. Remarkably, this is the only time Aristophanes shows a dishonest side to this exceptionally strong and charismatic character. In context, however, all it shows is that in leading the masses even good leaders must sometimes resort to the tactics of demagoguery (compare Lysistrate's handling of the Proboulos earlier).

57. Following the stylistic analyses provided by Fontenrose (166-95), one might be able to classify the Paphlagon's oracles as to their supposed sources. The Paphlagon began only by claiming Bakis as his authority (1003), and a number of the oracles he proclaims appear to have the appropriate form. But the diction of at least one of his oracles has a decidedly Delphic cast (1015-20). See Fontenrose's discussion (159) and Neil, note on 1015. 
who will replace the Paphlagon and is explicitly said to be Pythian in origin. ${ }^{58}$ This oracle, it turns out, is in every particular the god's own truth, as Paphlagon's wonderfully paratragical responses $(1237,1240,1243,1248-49)$ demonstrate..$^{59}$

In fact, despite all of Aristophanes' reservations about oracles and their purveyors, he offers us but one case of an allegedly Pythian oracle that we are led not to trust. Philokleon in Wasps claims to have received an oracle from Delphi stating that he would wither away if ever he judged in a defendant's favor (15860 ). His claim is a comic exaggeration of what such Athenian jurors believe: that leniency is a sign of decay. But one also suspects that Philokleon will say anything in his desperate desire to return to jury duty. One is not led to distrust Delphic authority.

The contrast between the passivity of the Pythia and the aggressiveness of the oracle-mongers is striking. Unsolicited prophecy was not a source of Delphi's reputation, and any such prophecy would thus be immediately set apart from those emanating from Delphi or any other shrine. ${ }^{60}$ The Bakid and Sibylline oracles collected by the oracle-mongers do not appear to have been solicited, however; at least by the time we hear of them, their context and initial relevance, if any, has been long forgotten. Certainly, their employment in politics and political rhetoric appears to have been unsolicited. Such an employment of oracles may have appeared to many as in and of itself an abuse of oracular languaye-or as grounds for suspecting the authenticity or authority of the oracles so employed. ${ }^{61}$

58. The relationship between this oracle and the first oracle read in the play (197-201), which had been stolen by Demos' two hapless slaves, is an interesting one. Both specify that it will be a sausage-seller who replaces the Paphlagon. The "Pythian" oracle at 1229-30 is never read, but seems to have some different content from the one that is read at 197-201. The earlier oracle states only that a sausage-seller will replace the Paphlagon, whereas the later "Pythian" oracle specifies in very comical ways where Paphlagon's replacement was educated (1235-36), what tactics he learned at wrestling school (1238-39), his trade (1241-42), and where that trade was practiced (1245-47). The earlier oracle, as well, has the diction of a Bakid oracle, beginning with the telltale words "But when ..." (on which see references supra n.46). So it looks as though the two oracles predict the same event, but are distinct oracles and predict it differently.

59. Strauss's own conclusions are markedly different: on his view, what Demos learns in the oracular agon of the Knights is that "every oracle-whether of Bakis or of Apollon or of anyone else-can be matched by an oracle of the opposite purport and that the same oracle can easily be interpreted to predict opposite things" (99). This understanding not only ignores the evidence for Aristophanes' regard for Delphi, it badly distorts the text. For one thing, Demos nowhere implies that he has learned not to be manipulated by oracles; far from it, he has once again been manipulated by oracles. And Demos does not say that he is won over by the Sausage-seller; he says he is won over by the wisdom of Glanis (1097).

60. See Garland 81; also 119: "The oracle could sanction but it could not propose. The evidence for an unsolicited prophecy emanating from an oracular shrine before the Hellenistic period is so slight as to be practically negligible." See also Parker 318.

61. Parker distinguishes "besought" from "self-offering" oracles and says that "besought oracles" "had quite different authority from the 'oracles of Bacis' and the like that oracle-collectors chanted, influential though these could be as precipitants of public opinion. An 'oracle of Bacis' adduced by a speaker was one argument in a debate, not an agreed means of resolving it" (298). As Parker says later (300), "Divination fails of its function if its objectivity is not convincingly demon- 
One final bit of evidence supports this view. Oliver and Mikalson hypothesize that the chresmological profession virtually disappeared from Athens after the Sicilian disaster. ${ }^{62}$ I think they overstate the case, ${ }^{63}$ but the evidence Aristophanes provides on this issue suggests that something at least has changed for the diviners. Of the plays produced before the loss of the fleet became known in Athens (Acharnians, Knights, Clouds, Wasps, Peace, Birds), three contain extended scenes in which the oracle-mongers are attacked, and one of the others (Clouds) has at least one sharp attack on the seers (332). But in the plays following the news from Sicily (Lysistrate, Thesmophoriazousai, Frogs, Ekklesiazousai, Wealth), only one has an attack on the manipulative use of oracles (Lysistrate 767-80), and this is a brief and singular interlude in a play produced not long after the event. The others either never mention divination, or do so only obliquely, in a way that has nothing to do with its political employment (Frogs 1319), or do so in a favorable way (Wealth-see my discussion above). Even if the oracle-traders had not gone bust, as Oliver and Mikalson suppose, it would appear at least that their political influence was no longer a fit subject for comedy. ${ }^{64}$

So it is that Aristophanes may be seen as making his jokes not so much at the expense of divination in general, or even of divination by oracles; rather, he stresses the abuses of divination by authority and its strategies in public debate and accordingly objects to the sources of divination that lend themselves too readily to such abuses. Oracles reported to be Bakid or Sibylline thus become the special focus of Aristophanes' satires. Delphi is treated with noticeably more respect; other oracular shrines are mentioned only in passing. ${ }^{65}$

In all of this, the outlook Aristophanes presents to us is consistent with what his plays emphasize on other issues. Aristophanes loves to expose frauds and manipulators; so it is that he ridicules both sophists and oracle-mongers. Aristophanic plays invariably encourage their audience to beware of high-flown windbags and not to be dazzled by con artists; so it is that he blasts Kleon and requires Strepsiades to come to his senses, and gets us to cheer for the likes of Dikaiopolis and Trygaios. Gullibility is thus anathema to Aristophanes, for his playshowever fantastic their plots and operations may be-always emphasize the ability of his successful characters to find their own ways out of their problems. This is folk wisdom-really, a celebration of simple common sense-for his characters' successes are never predicated upon special talents or training. Aris-

strated." Plainly, the "self-offering" oracles of the oracle-mongers were always employed in circumstances where the objectivity of the one employing them could not be assumed.

62. Oliver 30; Mikalson 40.

63. See Fontenrose 153; Garland 82. Seers and oracle-mongers continued to be mentioned in comic works by other poets; see, e.g., Plato Sph. (produced ca. 403), fr. 147A (Edmonds), and Archippus Fishes (produced ca. 401), fr. 15 (Edmonds).

64. Birds 716.

65. Ammon: Birds 619, 716; Dodona: Birds 716. 
tophanes' plays, especially Knights, Peace, and Birds, emphasize the power we all have to go about our business without recourse to exotic nonsense. Of course, cleverness and deceitfulness are not of themselves character flaws, as the heroic example of Odysseus shows. But it is always best to be alert to others' tricks. The value of a shrewd awareness of the possibilities for deception is expressed in Greek literature from Homer and Hesiod on, and was no doubt a part of Greek culture even before their time. So Aristophanes in this regard must not be supposed to be a creature of the late fifth and early fourth centuries, and where such an awareness is featured in his plays it should not be taken as a sign of his times.

Virginia Polytechnic Institute and State University

\section{BIBLIOGRAPHY}

Argyle, A. W. "Chresmologoi and Manteis." CR 20 (1970) 139.

Bouché-Leclercq, A. Histoire de la divination dans l'antiquité. Vols. 1-4. Paris 1879-1882 (repr. New York 1975).

Burkert, Walter. Greek Religion. Trans. John Raffan. Cambridge, Mass. 1985.

Culianu, I. P. “Iatroi kai manteis: Sulle strutture dell'estatismo greco." Studi Storico-religiosi (Rome) 4 (1980) 287-303.

Defradas, Jean. "La Divination en Grèce." In La Divination, ed. André Caquot and Marcel Leibovici, vol. 1, 157-95. Paris 1968.

Delatte, A. La Catoptromancie grecque et ses dérives. Liège 1932.

Devereux, George. Dreams in Greek Tragedy. Oxford 1976.

Dodds, E. R. The Greeks and the Irrational. Berkeley and Los Angeles 1951.

Dover, Kenneth J. Aristophanic Comedy. Berkeley and Los Angeles 1972.

Edmonds, John Maxwell. The Fragments of Attic Comedy. Leiden 1957.

Ehrenberg, Victor. The People of Aristophanes. New York 1962.

Engle, Judith M. Playing about the Stage: Poetics, Ritual, and Demogoguery in the Knights of Aristophanes. Diss. Princeton 1983. (Microfiche, Ann Arbor 1983.)

Flacelière, Robert. Greek Oracles. Trans. Douglas Garman. London 1965.

Fontenrose, Joseph. The Delphic Oracle. Berkeley and Los Angeles 1978.

Galy, J. M. "La Critique religieuse dans la comédie grecque des Ve et IVe S." Annales de la Faculté des Lettres et Sciences Humaines de Nice 21 (1974) 17383.

Garland, R. S. J. "Religious Authority in Archaic and Classical Athens." $B S A$ 79 (1984) 75-123.

Halliday, William R. Greek Divination. London 1913.

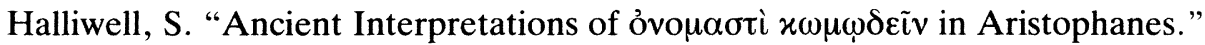
CQ 34 (1984) 83-88.

Harriott, Rosemary M. Aristophanes: Poet and Dramatist. Baltimore 1986. 
Hook, La Rue van. "Crime and Criminals in the Plays of Aristophanes." CJ 23 (1928) 275-85.

Horn, W. Gebet und Gebetsparodie in den Komöder des Antikes. Nuremberg 1970. Jordan, Borimir. "Religion in Thucydides." TAPA 116 (1986) 119-47.

Kassel, R., and C. Austin. Poetae Comici Graeci (PCG). Vol. III.2: Aristophanes (Berlin 1984). Vol. IV: Aristophon-Crobylus (Berlin 1983). Vol. V: Damoxenus-Magnes (Berlin 1986).

Kleinknecht, H. Die Gebetsparodie in der Antike. Stuttgart 1937.

Köckert, H. Aristophanes und die Religion: Zum Verhaeltnis von Komik und Religion in der Aristophanischen Komödie. Diss. Leipzig 1976.

Latte, Kurt. "Orakel.” RE 18.850-52 (1939).

Lewis, Naphtali. Dreams and Portents. Toronto 1980.

Lloyd, G. E. R. Magic, Reason, and Experience. Cambridge, Eng. 1979.

Lloyd-Jones, Hugh. "The Delphic Oracle.” G\&R 23 (1976) 60-73.

Marinatos, N. "Thucydides and Oracles." JHS 101 (1981) 138-40.

Martinazzoli, F. "La religiosita se Sofocle ed un luoso di Aristofane." Il Mondo Classico (1941) suppl. 30-4.

Meier, Carl A. "The Dream in Ancient Greece." In The Dream and Human Society, ed. Gustav E. von Grunebaum and Roger Callois, 303-19. Berkeley and Los Angeles 1966.

Mikalson, Jon D. Athenian Popular Religion. Chapel Hill 1983.

Neil, Robert Alexander. The Knights of Aristophanes. Hildesheim 1966.

Nestle, Wilhelm. Griechische Religiosität vom Zeitalter des Perikles bis auf Aristoteles (vol. 2 of Die griechische Religiosität in ihren Grundzügen und Hauptvertretern vom Homer bis Proklos). Berlin 1933.

Nilsson, Martin P. Cults, Myths, Oracles, and Politics in Ancient Greece. New York 1951 (repr. 1972).

- Geschichte der griechischen Religion. Vol. 13. Munich 1967.

- Greek Folk Religion. New York 1940 (repr. 1971). . A History of Greek Religion ${ }^{2}$. Oxford 1952 (repr. 1964).

Nock, Arthur D. "The Religious Attitudes of the Ancient Greeks." Proceedings of the American Philosophical Society 85 (1942) 472-82. Reprinted in Arthur Darby Nock: Essays on Religion and the Ancient World, ed. Zeph Stewart. 2 vols. Cambridge, Mass. 1972.

Oliver, James H. The Athenian Expounders of the Sacred and Ancestral Law. Baltimore 1950.

Ostwald, M. "The Prytaneion Decree Re-Examined." AJPh 72 (1951) 24-46. Parke, Herbert W. The Oracles of Zeus. Oxford 1967.

Parke, Herbert W., and Donald E. W. Wormell. The Delphic Oracle. Vols. 1-2. Oxford 1956.

Parker, Robert C. T. "Greek States and Greek Oracles." In Crux: Essays Presented to G. E. M. de Ste. Croix on His 75th Birthday. History of Political Thought 6 (1985) 298-326. 
Platnauer, Maurice, ed. Aristophanes' "Peace." Oxford 1964.

Powell, C.A. "Religion and the Sicilian Expedition." Historia 28 (1979) 15-31.

Price, Simon. "Delphi and Divination." In Greek Religion and Society, ed. P. E.

Easterling and J. V. Muir, 128-54. Cambridge, Eng. 1985.

Pritchett, William K. The Greek State at War. Vol. 3. Berkeley and Los Angeles, 1980.

Reckford, Kenneth J. "Catharsis and Dream-Interpretation in Aristophanes' Wasps." TAPA 107 (1977) 283-312.

Rogers, Benjamin Bickley. Aristophanes (Loeb Classical Library). Cambridge, Mass. 1924. Vol. 1: Acharnians, Clouds, Knights, Wasps. Vol. 2: Peace, Birds, Frogs. Vol. 3: Lysistrata, Thesmophoriazusae, Ecclesiazusae, Plutus.

Roth, P. A. Mantis: The Nature, Function, and Status of a Greek Prophetic Type. Diss. Bryn Mawr 1982.

Sommerstein, Alan H. The Comedies of Aristophanes. Chicago 1980-1985. Vol.

1: Acharnians. Vol. 2: Knights. Vol. 3: Clouds. Vol. 4: Wasps. Vol. 5: Peace.

Straten, F. T. van. "Daikrates' Dream: A Votive Relief from Kos, and Some other Kat'Onar Dedications." BABESCH (Bulletin Antieke Beschaving) 51 (1976) 1-38.

Strauss, Leo. Socrates and Aristophanes. New York 1966.

Van Leeuwen, J. Aristophanis (Greek texts and Latin commentary). Leiden 1893-1901. Vol. 1: Vespae, Aves, Lysistrata, Thesmophoriazusae, Plutus. Vol. 2: Ranae, Nubes, Equites, Acharnenses.

Weinrich, O. "Die Seher Bakis und Glanis, ein Witz des Aristophanes." Archiv für Religionswissenschaft (1929) 57-60.

Woodward, A. M. "Athens and the Oracle of Ammon." BSA 57 (1962) 5-13. Ziehen, L. "Hiereis." RE 8.1345-55 (1913). 